\title{
KONTEKST REFORMY STUDIÓW PRAWNICZYCH
}

\section{WPROWADZENIE}

Jedną z myśli, które podczas aplikacji sądowej zapadły mi najtrwalej w pamięć, jest ta, że „dobry sędzia poradzi sobie ze złą ustawą, natomiast kiepski sędzia może zrobić zły użytek także z dobrego prawa". Nowy kontekst odczytania tych słów dała mi niedawna lektura pracy, której autorzy za pomoca ekonomicznej analizy prawa starali się odpowiedzieć na pytanie o znaczenie recepcji prawa rzymskiego w latach 1200-1600 dla wzrostu gospodarczego Europy w tamtym okresie. Badania te pokazały wyraźnie, że przesłanki ówczesnego postępu ekonomicznego upatrywać należy nie w samej treści przejętego z różną intensywnością ius civile, ale w rozwiniętych na tej podstawie metodach prawniczego myślenia i upowszechnieniu się uniwersyteckiego modelu kształcenia tej umiejętności ${ }^{1}$. Już te dwie pozornie odległe od siebie refleksje kierują uwagę ku myśli, że to właśnie specyficzny sposób prawniczego myślenia jest kluczowy dla społecznej akceptacji i ekonomicznej efektywności prawa. Dlatego odpowiedź na pytanie o dobre kształcenie prawnika musi zawsze łączyć się - moim zdaniem - z pytaniem, czy prowadzi ono do zbudowania sposobu prawniczego myślenia najbardziej adekwatnego do potrzeb współczesności.

Nie mamy w Polsce pogłębionej refleksji naukowej na temat nauczania prawa $^{2}$, a nieliczne obszerniejsze publikacje $\mathrm{z}$ tego zakresu nie stały się zaczynem intensywnej, krytycznej dyskusji ${ }^{3}$. Publikowane co jakiś czas krótkie wypowiedzi na temat modelu studiów prawniczych skupione są wokół tradycyjnie rozumianego sporu między praktyczną a akademicką wizją studiów prawniczych jako parytetów przedmiotów dogmatycznych i teoretyczno-historycznych. W 2012 r. dyskusję tę ożywiły kontrowersje wokół zasadności dwustopniowego wykształcenia prawniczego ${ }^{4}$. Powtarzającym się elementem

${ }^{1}$ H. B. Schäfer, A. J. Wulf, Jurists, Clerics and Merchants. The Rise of Learned Law in Medieval Europe and its Impact on Economic Growth, „German Working Papers in Law and Economics” 2013, article 2, http://www.bepress.com/gwp/default/vol2013/iss1/art2 (dostęp: 25.10.2013).

${ }^{2}$ Zob. B. Sitek, P. Polaczuk, Reforma szkolnictwa wyższego. Ksztatcenie prawników w Polsce na tle doświadczeń innych państw europejskich, „Forum Prawnicze” 2012, nr 5 (13), s. 10; P. Machnikowski, Szkoty bezrobotnych prawników?, „Na Wokandzie” 2013, nr 4 (18), s. 48.

${ }^{3}$ Zob. F. Zoll, Jaka szkoła prawa?, Łódź 2004; E. Kozerska, P. Sadowski, A. Szymański (red.), Wybrane problemy nauki i nauczania prawa, Opole 2010.

${ }^{4}$ Zob. wyżej w tym numerze: E. Borkowska-Bagieńska, Wokót reformy studiów prawniczych (tam wybrana dalsza literatura). 
wypowiedzi na ten temat jest przekonanie o potrzebie odnowienia modelu kształcenia, którego kontekst tworzą dziś głębokie zmiany w sposobie funkcjonowania prawa, zasady finansowania i zarządzania szkół wyższych oraz upowszechnianie się tzw. systemu bolońskiego. Tu tkwią przesłanki, ale i potencjalne przeszkody rzeczywistego postępu w modernizacji edukacji prawniczej. Odwołując się do spostrzeżeń poczynionych na wstępie, uważam, że kryterium rzeczywistego postępu powinno być w przede wszystkim przekazywanie umiejętności prawniczego myślenia adekwatnej do potrzeb współczesności.

Dzisiejszą dyskusję o kształceniu prawników warto zatem rozbudować o szczegółowe pytania dotyczące relacji między wskazanym kierunkiem pożądanej zmiany a kontekstem tych zmian. Jedno z nich brzmi: Czy model dwustopniowych studiów prawniczych może przynieść korzystne zmiany dla kształcenia prawników w Polsce?

\section{ISTOTA NOWYCH WYZWAŃ DLA PRAWNIKA PRAKTYKA}

Dziewiętnastowieczna idea zapewnienia stabilności i pewności prawa przez wyczerpującą regulację ustawową szybko ujawniła swe słabości. Ich miarę w odniesieniu do prawa prywatnego kontynentalnej Europy wyraża wprowadzenie w końcu lat siedemdziesiątych minionego stulecia pojęcia dekodyfikacji dla określania nowego etapu $\mathrm{w}$ losach prawa ${ }^{5}$. Jako jego zasadnicze cechy wskazuje się znaczny wzrost liczby szczegółowych regulacji prawnych, obejmujących te same zagadnienia praktyczne co kodeks, ale często nieskoordynowanych $\mathrm{z}$ kodeksem ani między soba; występowanie $\mathrm{w}$ ustawach (jako skutek politycznych kompromisów) niejasności w brzmieniu przepisów oraz częste nowelizacje; stały wzrost znaczenia prawotwórczej w istocie interpretacji prawa przez sądy; utratę państwowego monopolu na rozwijanie krajowego porządku prawnego w następstwie procesów integracji regionalnej, w szczególności europejskiej, oraz funkcjonowanie ponadnarodowych trybunałów. Systemową konsekwencją tych zjawisk jest dążenie do policentryczności porządku prawnego, wyrażającego się w tym, że oparty na kodyfikacyjnych założeniach jednolity system jest zastępowany przez niezależne od siebie ustawowe mikrosystemy ${ }^{6}$. W powiązaniu ze wzrostem tzw. prawa sędziowskiego prowadzi to do podania $\mathrm{w}$ watpliwość dwóch fundamentalnych założeń współczesnego prawoznawstwa: rozumienia istoty prawa jako jednego $\mathrm{z}$ atrybutów władzy publicznej oraz wiary, że warunkiem efektywności prawa jest ujęcie go w scentralizowany formalny system ${ }^{7}$. W konsekwencji zasadnicze oczekiwania

\footnotetext{
${ }^{5}$ N. Irti, L'età della decodificazione, Varese 1979, s. 22 i n.

${ }^{6}$ Zob.: E. Łętowska, Multicentryczność wspótczesnego system prawa i jej konsekwencje, „Państwo i Prawo” 2005, z. 4, s. 3 i n.; W. Lang, Wokót multicentryczności systemu prawa, „Państwo i Prawo” 2005, z. 7, s. 95 i n.; E. Kustra, Wokót problemu multicentryczności systemu prawa, „Państwo i Prawo” 2006, z. 6 , s. 85 i n.

${ }^{7}$ T. Giaro, Prawo i historia prawa $w$ dobie globalizacji. Nowe rozdanie kart, w: idem (red.), Prawo $w$ dobie globalizacji. Konferencja Wydziału Prawa i Administracji Uniwersytetu Warszawskiego, 5 marca 2010, Warszawa 2011, s. 76-77.
} 
w stosunku do działającego w takim środowisku prawnika sprowadzają się, po pierwsze, do technicznej umiejętności znalezienia istotnych dla rozwiązania konkretnego problemu regulacji i orzeczeń, a po drugie - do zdolności budowania twórczej argumentacji prawniczej, prowadzącej do rozwiązania trudnych przypadków przy uwzględnieniu zasad i fundamentalnych wartości oraz społecznych i ekonomicznych konsekwencji rozstrzygnięcia. Adekwatna do takich oczekiwań praktycznych zmiana prawniczego kształcenia powinna zatem polegać na przesunięciu punktu ciężkości z uczenia formalnych podziałów i treści przepisów ku opartej na doświadczeniu i sprawdzonej przez szereg ćwiczeń argumentacyjnych wiedzy o tym, jakie sa społeczne i ekonomiczne funkcje poszczególnych uprawnień i obowiązków, jakie wartości konkuruja przy ich wykonywaniu oraz jak wytyczyć równowagę między tymi wartościami, gdy prawo pozytywne nie daje jednoznacznej odpowiedzi. Elastyczne, pragmatyczne podejście do rozstrzygania konfliktów prawnych poprzez proceduralny dyskurs przywołuje na myśl tradycję anglosaskiego common law ${ }^{8}$.

\section{ANGLOSASKI MODEL DWUSTOPNIOWYCH STUDIÓW PRAWNICZYCH}

Obserwacja modelu kształcenia prawników w Anglii pozwala uznać, że wprowadzanie tam bolońskiego systemu kształcenia jest daleko zaawansowane dlatego, że Wielka Brytania jest dla niego wzorem. Podstawowa dziś w Anglii droga do zawodu adwokata (barrister, solicitor) obejmuje bowiem trzyletnie akademickie studia prawnicze uwieńczone uzyskaniem tytułu Bachelor of Laws (LL.B), a na niektórych uniwersytetach Bachelor of Arts (B.A.), rok studiów praktycznych organizowanych przez niektóre uniwersytety wspólnie z adwokatura (Law Society) oraz dwa lata przygotowania praktycznego w kancelariach (chambers dla barristers albo law firms dla solicitors) ${ }^{9}$. Jednakże właściwa ocena kształcenia prawniczych umiejętności przez trzyletnie studia w Anglii wymaga zwrócenia bliższej uwagi na to, w jaki sposób i ile osób przyjmuje się na te studia, jaki jest styl i jakie sa główne treści nauczania.

W krajach anglosaskich szanse na dobra pracę w zawodzie adwokata sa mocno powiązane $\mathrm{z}$ tym, jaką szkołę prawa się skończyło. Fundamentem działania tych szkół jest przekonanie, że pomyślne ukończenie studiów prawniczych wymaga szczególnych zdolności i dlatego dostęp do nich musi być ograniczony do osób spełniających to wymaganie. Jak dużą ma to wagę, pokazuje fakt, że reakcją na zawyżanie ocen na tzw. świadectwie wykształcenia średniego (General Certificate of Secondary Education $)^{10}$ było utworzenie w 2004 r. przez konsorcjum czołowych angielskich szkół prawa szczególnej procedury doboru kandydatów na studia. Nosi ona nazwę National Admissions

\footnotetext{
${ }^{8}$ Zob. H. P. Glenn, The Legal Traditions of the World, Oxford 2000, s. 218-220.

${ }^{9}$ M. Trybus, Großbritannien, w: Ch. Baldus, T. Finkenauer, T. Rüfner (red.), Bologna und das Rechtsstudium, Tübingen 2011, s. 78 i 95.

${ }^{10}$ Zob. M. Trybus, op. cit., s. 86.
} 
Test for Law, a jej istotą nie jest sprawdzenie wiedzy, ale wybranie tych spośród kandydatów, którzy mają największy potencjał do studiowania prawa. W celu ustalenia zdolności kandydata $\mathrm{w}$ zakresie rozumienia $\mathrm{i}$ interpretacji oraz umiejętności analizy, syntezy, indukcji i dedukcji ${ }^{11}$ uczestnik testu musi wskazać najcelniejsze sformułowanie spośród pięciu streszczających każdy $\mathrm{z}$ podanych w teście dwunastu tekstów (o objętości od 400 do 600 słów) ${ }^{12}$ oraz napisać esej o objętości nieprzekraczającej 750 słów na jeden z pięciu wskazanych tematów ${ }^{13}$. Efektem takiej weryfikacji jest to, że na wymagające ponoszenia wysokich opłat studia prawnicze dostaje się tylko około $20 \%$ kandydatów. Liczba studentów prawa na czołowych uniwersytetach Wielkiej Brytanii, kraju mającego ponad 60 milionów obywateli i szeroko znany w świecie język, jest znacznie mniejsza niż na wydziałach prawa polskich uniwersytetów. Przykładowo w 2012 r. w Cambridge rozpoczęło studia 215 osób $^{14}$, w Oksfordzie $-187^{15}$, a w Edynburgu $-155^{16}$. Rozwijaniu predyspozycji studentów do rozwiązywania problemów prawnych służy uzupełnienie wykładów zajęciami w małych grupach (tzw. tutorial). Są one organizowane przez colleges - właściwe dla struktury angielskich uniwersytetów. W Oksfordzie i Cambridge taki cotygodniowy tutorial prowadzi się dla dwóch, trzech studentów. W innych angielskich uniwersytetach liczba ta nie przekracza dwudziestu osób ${ }^{17}$. Konsekwencją położenia nacisku na kształtowanie umiejętności prawniczego myślenia jest w końcu mała liczba przedmiotów obowiązkowych $^{18}$. W odróżnieniu od polskich curricula oznacza to brak lub niewielki udział tzw. przedmiotów historycznych i ogólnoteoretycznych, szczegółowych dyscyplin dogmatycznych, $\mathrm{w}$ tym procedur. Właściwa interpretacja tego stanu rzeczy wymaga jednak wskazania, że specyfika angielskiego porządku

${ }^{11}$ LNAT: National Admissions Test for Law, New York 2006, s. 4.

12 Zob. test przykładowy: http://www.lnat.ac.uk/lnat-preparation/practice-tests.aspx (dostęp: 27.10.2013). Przeznaczony na to czas wynosi 95 minut. Jeden z tekstów prezentował dowody Tomasza z Akwinu na istnienie Boga, takie jak: konieczność istnienia pierwszej przyczyny ruchu i istnienia samoistnej istoty będącej przyczyną świata, istnienie czegoś niematerialnego koniecznego do powstania materii i istnienie bytów różnej doskonałości zakładające istnienie istoty najdoskonalszej. Towarzyszy temu komentarz, że trzy pierwsze łączy odwoływanie się do nieskończonego ciągu (infinite regress) oraz że wywołuje to wątpliwości. Kandydat ma wskazać, który z pięciu zwrotów oddaje najlepiej istotę użytego w tym kontekście sformułowania infinite regress. Dane do wyboru wyjaśnienia to: musiał być taki czas, gdy nie istniało nic materialnego; coś spowodowało pierwszy ruch; ad infinitum; nic nie dzieje się bez przyczyny oraz jedyną ucieczką jest Bóg.

${ }^{13}$ Przeznaczony na to czas wynosi 40 minut. Jako przykłady takich tematów można wskazać: W jakich okolicznościach aborcja powinna być dozwolona i dlaczego?; Czy zgadzasz się, że podróże turystyczne prowadzą do wyzysku ubogich narodów i przynoszą korzyści tylko bogatym?; Igrzyska olimpijskie dziś są w mniejszym stopniu sprawdzianem tężyzny fizycznej a bardziej miarą narodowych inwestycji i wpływów. Czy zgadzasz się?; Noszenie w krajach zachodnich nakrycia głowy (burki) przez muzułmanki jest równie obraźliwe jak noszenie bikini w krajach arabskich. Czy zgadzasz się?; , Kobieta może współcześnie osiągnąć wszystko, czego chce”. Jak się odniesiesz do tej opinii?

${ }^{14}$ Wybrani spośród 1021 kandydatów; zob. http://www.study.cam.ac.uk/undergraduate/apply/ statistics/ (dostęp: 28.10.2013).

${ }^{15}$ Wybrani spośród 1226 kandydatów, zob. http://www.ox.ac.uk/about_the_university/facts_and_ figures/undergraduate_admissions_statistics/(dostęp: 28.10.2013).

${ }^{16}$ Wybrani spośród 1549 kandydatów, zob. http://www.ed.ac.uk/polopoly_fs/1.104225!/file Manager/2012\%20for\%20web.pdf (dostęp: 28.10.2013).

${ }_{17}$ M. Trybus, op. cit., s. 84.

18 Ibidem, s. 80-82. 
prawnego sprawia, że nie ma tam tak wyraźnego, jak na kontynencie europejskim, rozdzielania prawa dawnego i współczesnego. Przykładowo, rozważając angielskie prawo umów ${ }^{19}$ czy własności ${ }^{20}$, musimy sięgać do orzeczeń nawet sprzed kilkuset lat, które polski prawnik uznałby za domenę historii prawa. Nadto argumenty historyczne stanowia element wykładów z komparatystyki prawniczej, która, choć zasadniczo fakultatywna, odgrywa ważniejszą rolę niż w Polsce. Szczegółowe dyscypliny dogmatyczne są przedmiotami do wyboru, które w całości lub większości wypełniaja ostatni, trzeci rok studiów.

Kształt i metody nauczania prawa w Anglii, czy szerzej w krajach tradycji common law, sa przedmiotem systematycznej, krytycznej debaty. Podejmowane w jej ramach tematy pokazuja, że nie ma tam wyraźnego sprzeciwu, czy choćby zasadniczego sporu, co do efektywności trzyletnich uniwersyteckich studiów prawniczych. Kluczowym wyrażeniem w dyskusji o kształceniu prawników pozostaje zwrot understanding law, czyli formowanie prawniczego myślenia ${ }^{21}$. Dążenie do realizmu w tym zakresie kieruje coraz intensywniej uwagę dyskutantów ku kulturowemu i technologicznemu środowisku, w jakim toczy się nauczanie i stosowanie prawa ${ }^{22}$. Poszukuje się analogii między historycznym doświadczeniem przełomów w nauce prawa a stanem dzisiejszym ${ }^{23}$. Oceniając $\mathrm{z}$ zewnątrz ten stan rzeczy, myślę, że w dużym stopniu tłumaczy go wskazana wyżej elitarność tych studiów w Anglii, rozwijanie umiejętności prawniczych przez skupienie uwagi studentów na podstawowych zasadach i liniach ewolucji systemu prawnego, które w dużym stopniu ukształtowała praktyka prawna, oraz wyraźne powiązanie $\mathrm{w}$ angielskiej argumentacji prawniczej takiego tradycjonalizmu $\mathrm{z}$ kryterium praktyczności i rozsądku. Last but not least, angielskie wykształcenie prawnicze prowadzi tylko do zawodu adwokata (barrister, solicitor). Dostępna sędziemu możliwość szerokiego rozwijania prawa przez twórczą argumentację staje się udziałem tylko tych, którzy przeszli głęboką weryfikację praktyczną, tj. odnieśli sukces w zawodzie adwokata.

Poczynione uwagi można z polskiej perspektywy odbierać jako inspirację co do kierunku zmian w kształceniu prawników, które uczynią absolwentów lepiej przygotowanymi do współczesnych wyzwań w stosowaniu prawa. Przywoływanie angielskiego przykładu jako argumentu za wprowadzeniem dwustopniowych studiów prawniczych w naszym kraju musi jednak budzić wątpliwości ze względu na specyficzny kontekst trzyletnich studiów prawniczych w Anglii.

$19 \mathrm{~Np}$. do klasycznych orzeczeń wykorzystywanych w nauczaniu o wadach oświadczenia woli należy sprawa Hastie v. Counturier z 1853 r.; zob. J. C. Smith, Smith and Thomas: A Casebook on Contract, London 2000, s. 495 i n.

${ }^{20} \mathrm{~Np}$. w wykładzie poświęconym odpowiedzialności związanej z przekazaniem gruntu do czasowego władania omawia się linię orzeczniczą, sięgając po wyrok z początku XVII w. w sprawie Barnard $v$. Godscall; zob. R. J. Smith, Property Law, Harlow 2000, s. 414.

${ }^{21}$ P. Maharg, Transforming Legal Education: Learning and Teaching the Law in the Early Twenty-first Century, Aldershot 2007, s. 96.

${ }^{22}$ Tak np.: ibidem, s. 1 i n.; P. Moraitis, H. Murphy, Language, Law and Identity: A Language and Learning Response to the Challenges of Widening Participation of Students in Law Subjects, ,The Law Teacher" 47, 2013, nr 2, s. 159-191.

${ }^{23}$ Zob. P. Maharg, op. cit., s. 119-146. 
Ostrożność w tej kwestii kieruje uwagę ku niemieckiej dyskusji na ten temat. Niemiecka kultura prawa ma bowiem - podobnie jak anglosaska - znaczenie światowe, a jest nam bliższa od angielskiej.

\section{NIEMIECKA KRYTYKA DWUSTOPNIOWYCH STUDIÓW PRAWNICZYCH}

Obecny model jednolitych niemieckich studiów prawniczych, kończących się tzw. pierwszym egzaminem państwowym, ma ponad 250-letnią tradycję ${ }^{24}$. To jeden z filarów niemieckiej kultury prawnej, w której jako zasadniczy cel kształcenia prawników wskazuje się formowanie zdolności do samodzielnego, odpowiedzialnego podejmowania rozstrzygnięć w sposób uwzględniający i wspierający systemową racjonalność porządku prawnego ${ }^{25}$. Zainicjowany Deklaracją bolońska z 1999 r. ${ }^{26}$ polityczny proces tworzenia Europejskiego Obszaru Szkolnictwa Wyższego oznaczałby istotna zmianę tego tradycyjnego modelu edukacji prawniczej i już z tego powodu wywołał żywą dyskusję. Przyniosła ona $\mathrm{z}$ jednej strony kilka propozycji kompromisu między wcześniejszą tradycją studiów prawniczych a tzw. modelem bolońskim ${ }^{27}$. $\mathrm{Z}$ drugiej strony wyraźnie formułowane były w debacie publicznej głosy sprzeciwu wobec zmiany niemieckiej edukacji prawniczej w sposób dostosowujący ja do procesu bolońskiego. W maju 2011 r. Konferencja Ministrów Sprawiedliwości z poszczególnych krajów niemieckich (Konferenz der Justizministerinnen und Justizminister) wyraziła pogląd, że przyjęcie adekwatnego do Deklaracji bolońskiej modelu wykształcenia prawniczego w wielu krajach nie przyczyniło się do ujednolicenia studiów prawniczych. Ministrowie uznali, że przyjęcie tego modelu w Niemczech przyniosłoby więcej strat niż korzyści dla jakości wykształcenia prawniczego ${ }^{28}$. W powiązanej $\mathrm{z}$ tą uchwała dyskusji akcentowano nie tylko brak postępu w ujednolicaniu studiów prawniczych, lecz także to, że dwustopniowość zwiększa trudności w krajowej i międzynarodowej mobilności studentów ${ }^{29}$. Jako inne argumenty uzasadniające wątpliwości lub

${ }^{24}$ P. Krause, Geschichte der Justiz- und Verwaltungsausbildung in Preußen und Deutschland, w: Ch. Baldus, T. Finkenauer, T. Rüfner (red.), Juristenausbildung in Europa zwischen Tradition und Reform, Tübingen 2008, s. 123.

${ }^{25}$ Zob. P.-C. Müller-Graff, Deutsche Juristenausbildung im internationalen Kontext, w: Ch. Baldus, T. Finkenauer, T. Rüfner (red.), Bologna..., s. 275.

${ }^{26}$ Jej tekst nie został opublikowany w „Dzienniku Urzędowym Wspólnot Europejskich”.

${ }^{27}$ H. Schöbel, Einführung des Bologna-Modells in der deutschen Juristenausbildung?, w: Ch. Baldus, T. Finkenauer T. Rüfner (red.), Bologna..., s. 253-255 (tam lit. na ten temat). Wzrost liczby niemieckich propozycji adaptacji modelu bolońskiego na studiach prawniczych $\mathrm{H}$. Schöbel tłumaczy, cytując żartobliwą wypowiedź bawarskiego ministra sprawiedliwości, który zauważył, że gdyby z Brukseli przyszło zalecenie, by budynki publiczne pomalować na niebiesko, a drzwi ozdobić żółtymi gwiazdami, to we wszystkich krajach członkowskich zapytano by: „Dlaczego?” - w Niemczech: „Do kiedy?”.

${ }^{28}$ Zob. http://www.sachsen-anhalt.de/fileadmin/Elementbibliothek/Bibliothek_Politik_und_Verwaltung/Bibliothek_MJ/jumiko/I_1_Juristenausbildung.pdf (dostęp: 25.10.2013).

${ }^{29}$ Raport Komisji Konferencji Ministrów Sprawiedliwości ds. Wykształcenia Prawniczego z 15.10.2005 r., cytuje za: H. Schöbel, op. cit., s. 258; Ch. Baldus, T. Finkenauer, T. Rüfner, Die Bologna-Reform aus Hochschullehrersicht, w: iidem (red.), Bologna..., s. 282. 
sprzeciw wobec dwustopniowości studiów prawniczych podnoszono w szczególności, że budowanie wykształcenia prawniczego, które nie jest zorientowane na konkretną sylwetkę zawodowa, byłoby nieodpowiedzialne ${ }^{30}$; powiązane z procesem bolońskim zmiany nie poprawią kontroli jakości niemieckich absolwentów prawa, która daje wieńczący studia zewnętrzny, obszerny pierwszy egzamin państwowy ${ }^{31}$; szanse na rynku pracy absolwentów pierwszego stopnia studiów prawniczych - w świetle badań - są niskie, a także groźbę usunięcia z programów studiów „ogólnego, naukowego wykształcenia” - niezbędnego dla kształcenia do klasycznych zawodów prawniczych ${ }^{32}$. Krytycznym ocenom modelu bolońskiego w Niemczech towarzyszyło wskazywanie słabości obecnego stanu rzeczy, jak masowość studiów prawnych ${ }^{33}$ i nadmierne ograniczenie przedmiotów ogólnego wykształcenia prawniczego (tzw. Grundlagenfächer) ${ }^{34}$. Wśród formułowanych w Niemczech propozycji zmian edukacji prawniczej spotykamy - właściwe modelowi angielskiemu - wprowadzenie postępowania sprawdzającego predyspozycje kandydatów ${ }^{35}$.

$\mathrm{Na}$ wstępie zwróciłem uwagę, że zmiany prawa prowadzą do zmiany oczekiwań związanych z umiejętnościami absolwentów tego kierunku. Opierając się na przedstawionych doświadczeniach zagranicznych mogę potwierdzić, że poszerzają one pole rozważań o procesie bolońskim jako ważnym elemencie kontekstu zmian zorientowanych na modernizację kształcenia prawników. Dostrzegamy bowiem kwestie, które zwykle nie sa poruszane w polskiej dyskusji dotyczącej relacji między dwustopniowością studiów prawniczych a rzeczywista poprawą kształcenia prawniczego w naszym kraju. Zestawmy je krótko w zakończeniu.

\section{ZAKOŃCZENIE}

Osią toczonego w Polsce sporu o celowość wprowadzenia dwustopniowych studiów prawniczych jest wymiar praktyczności tych studiów. Naszkicowane doświadczenia zagraniczne inspirują do zmiany rozumienia owej praktyczności. Nie powinna ona być mierzona liczbą szczegółowych przedmiotów dogmatycznych. Sama obecność w planie studiów przedmiotów teoretyczno-historycznych nie jest

30 J. Banzer (minister sprawiedliwości Hesji), Podiumdiskussion, w: Ch. Baldus, T. Finkenauer, T. Rüfner (red.), Juristenausbildung..., s. 357.

${ }^{31}$ J. Riedel (prezes Sądu Krajowego w Kolonii, ekspert komisji ds. reformy wykształcenia prawniczego), Podiumdiskussion, w: Ch. Baldus, T. Finkenauer T. Rüfner (red.), Juristenausbildung..., s. $363-364$.

${ }^{32}$ H. Schöbel, op. cit., s. 262-265.

${ }^{33}$ B. Dauner-Lieb (profesor Uniwersytetu w Kolonii, ekspert komisji ds. reformy wykształcenia prawniczego), Podiumdiskussion, w: Ch. Baldus, T. Finkenauer T. Rüfner (red.), Juristenausbildung..., s. 354.

${ }^{34}$ Ch. Baldus, Perspektywy nauki prawa $w$ świetle raportu niemieckiej Rady Nauki, „Forum Prawnicze" 2013, nr 1 (15), s. 16.

${ }^{35}$ H. Schöbel, op. cit., s. 271 (tam dalsza lit.). 
też gwarancją opanowania przez studentów oczekiwanych podstaw prawniczego myślenia. Przyjęty w Anglii test predyspozycji do studiów prawniczych i formułowane $\mathrm{w}$ tym zakresie postulaty $\mathrm{w}$ Niemczech pokazuja, że punktem wyjścia w budowie klasycznej edukacji prawniczej odpowiadającej potrzebom współczesności jest ograniczenie jej masowości. Odpowiedzialne kształcenie prawnicze powinno być dostępne dla tych, którzy wyróżniają się predyspozycjami do zrozumienia i stosowania efektywnych metod prawniczej argumentacji ${ }^{36}$. Przykład angielski pokazuje szczególnie wyraźnie, że w kierowanej do takich studentów ofercie dydaktycznej punktem ciężkości powinna być nie liczba przedmiotów, ale to, jak się ich uczy. Także w Polsce bardziej użyteczne do formowania prawniczego myślenia moga być zajęcia skupione na zasadach i wartościach prawa czy też strategiach argumentacyjnych w wielowiekowejpowiązanej ze współczesnościa - perspektywie niż scholastyczny wykład szczegółowej dyscypliny dogmatycznej ${ }^{37}$. W tym kontekście warto przywołać opinię, że jednym ze źródeł słabości amerykańskiej edukacji prawniczej jest rozpraszanie uwagi studentów zbyt wieloma szczegółowymi kazusami, przez co tracą oni zdolność dostrzegania ogólnych zasad prawa i krytycznej refleksji nad jego racjonalnością ${ }^{38}$.

Powracając do Europy - to, że w zakresie źródeł prawa i metod prawniczych jesteśmy bliżej Niemiec niż Anglii, skłania do podobnej jak u naszych sąsiadów ostrożności wobec skrócenia czasu studiów, otwierających drogę do klasycznych zawodów prawniczych. Praktyczność takich studiów rozumiana jako szkoła prawniczego myślenia dla wyróżniających się zdolnościami kandydatów jest, moim zdaniem, jedyną receptą na to, by wydziały prawa nie stały się kolejna „fabryką bezrobotnych” ${ }^{39}$. Model studiów dwustopniowych wydaje się natomiast racjonalnym rozwiązaniem korygującym i łagodzącym skutki postulowanego ograniczenia masowości klasycznych studiów prawniczych. Nie znam polskich badań co do szans na rynku pracy absolwentów pierwszego czy drugiego stopnia kierunku studiów bogatego w wyspecjalizowane treści prawnicze. Wyniki badań niemieckich pozwalaja jednak oczekiwać, że użyteczne na polskim rynku pracy mogą być studia prawno-ekonomiczne ${ }^{40}$. Umiędzynarodowienie tworzenia i stosowania prawa pozwala przypuszczać, że dobre szanse na rynku pracy mogą mieć także absolwenci studiów prawno-filologicznych.

Zaproponowany tu sposób rozumienia praktyczności studiów prawniczych musi - jak widzieliśmy - łączyć się ze zmianą obecnego modelu finansowania edukacji prawniczej. Podczas poszukiwań sposobów uzdrowienia tego problemu w Polsce warto odrębnie przybliżyć jakże odmienne od naszego doświadczenia

\footnotetext{
${ }^{36}$ W szczególności pożądane wydaje się wprowadzenie tego kryterium względem kandydatów na studia płatne, którzy co do zasady mieli gorszy wynik z matury.

${ }^{37}$ Analizując biografie wybitnych polskich prawników, Andrzej Zoll zauważył, że większość z nich, poza studiami ściśle prawniczymi, pogłębiała swe wykształcenie służące rozumieniu funkcji prawa i jego istoty; zob. A. Zoll, Przedmowa, w: K. Pol, Poczet prawników polskich, Warszawa 2000, s. XV.

38 A. Watson, The Shame of American Legal Education, Lake Mary 2006, s. 197-198.

${ }^{39}$ Zob. P. Machnikowski, op. cit., s. 48.

${ }^{40} \mathrm{~W}$ Niemczech studia takie prowadzone są w szerokim zakresie przez wyższe szkoły zawodowe i dlatego sceptycznie odniesiono się do upowszechnienia procesu bolońskiego przez tworzenie podobnych kierunków na wydziałach prawa; zob. H. Schöbel, op. cit., s. 260-263.
} 
angielskie i niemieckie $\mathrm{w}$ tym zakresie. W pierwszym wypadku jest to pełne finansowanie edukacji prawniczej przez studentów ${ }^{41}$. Cechami niemieckiego rozwiązania są natomiast: rygorystyczne określanie (bardzo niskiej w porównaniu z Polską) liczby etatów dydaktycznych, łączenie przez profesorów badania i nauczania dyscyplin dogmatycznych i teoretyczno-historycznych oraz rzeczywista konkurencja - o stanowisko profesorskie można się ubiegać jedynie na innym uniwersytecie niż ten, na którym uzyskało się habilitację.

Konkludując, tak jak rośnie w Polsce znaczenie standardów międzynarodowych przy ocenie jakości badań naukowych, tak również powinniśmy intensywniej wykorzystywać doświadczenia zagraniczne, by uchronić się przed ryzykiem powierzchownego rozumienia praktyczności i nowoczesności w potrzebnej reformie kształcenia prawników.

prof. dr hab. Wojciech Dajczak

Uniwersytet im. Adama Mickiewicza w Poznaniu

dajczak@amu.edu.pl

\section{THE CONTEXT OF THE REFORM OF LAW STUDIES}

\section{Summary}

The discussion on the reform of law studies in the last dozens or so years has been centred on a dispute whether the practical skills or academic knowledge shall prevail in the teaching of law. The author argues that the concept of practicality lies somewhere else. What is really important is to what extent studying law equips future graduates with the skills of legal reasoning, that is independent and rational solving of problems. A question is therefore asked if the British experience of a 3-year Bachelor's course in law and its criticism in Germany may help in the recent discussion whether the Bologna model should also be implemented in law schools in Poland. Consequently, what needs to be discussed includes issues such as: restriction of the availability of law studies by aptitude tests for candidates, a fewer number of obligatory subjects, or stronger ties between the teaching of contemporary law and its economic, cultural and historical context, together with explanation of legal principles and typical conflicts. It is concluded that law studies should last longer than three years, while the social and financial consequences of their lesser availability may be mitigated by other course options with substantial content of legal issues (e.g. law and economic, or law and linguistics).

${ }^{41}$ Art. 70 ust. 2 Konstytucji RP wyklucza proste przyjęcie tej zasady w naszym kraju. Jednak w głębszej dyskusji nad tą kwestią, w szczególności nad zakresem i sposobem finansowania nauki ze środków publicznych, celowe byłoby wnikliwe przeanalizowanie podstaw finansowych angielskich szkół prawa i różnorodne dostępne w Wielkiej Brytanii możliwości uzyskania wsparcia finansowego przez studentów. 
Copyright of Journal of Law, Economics and Sociology is the property of Faculty of Law and Administration of Adam Mickiewicz University in Poznan and its content may not be copied or emailed to multiple sites or posted to a listserv without the copyright holder's express written permission. However, users may print, download, or email articles for individual use.

Właścicielem praw autorskich do „Ruchu Prawniczego, Ekonomicznego i Socjologicznego” jest Wydział Prawa i Administracji Uniwersytetu im. Adama Mickiewicza w Poznaniu. Zawartość czasopisma nie może być kopiowana, przesyłana do innych stron internetowych bądź zamieszczana na blogach bez pisemnej zgody wydawcy. Niemniej artykuły można drukować, kopiować lub przesyłać w formie elektronicznej na własny użytek. 